\title{
The Estimation of Long-run Relationship between Serbian and German Economic Growth $^{3}$
}

Article history:

Received: 18 January 2016

Sent for revision: 5 February 2016

Received in revised form: 3 May 2016

Accepted: 16 May 2016

Available online: 11 July 2016

Abstract: Germany has always had an essential influence on Serbia's economic development. Today, Germany is Europe's economic and political superstar so this is even more pronounced. Hence, the aim of this paper is to explore the fundamental causal relationship between German and Serbian economy. In doing so, after the introductory part, where we emphasized interconnection in terms of investment, foreign trade, employment, new technologies etc., we are extending our study using quarterly 2004q1-2015q2 GDP data of both Serbia and Germany to estimate the Vector Error Correction model (VECM). The results suggest that there is co-integration between Serbia's and Germany's economic growth. The statistically significant negative coefficient on $\hat{e}_{t-1}$ indicates that Serbian GDP responds to a temporary disequilibrium between the Germany and Serbia. On the other hand, Germany does not appear to respond to a disequilibrium between the two economies; the t-ratio on $\hat{e}_{t-1}$ is statistically insignificant. These results support the idea that economic conditions in Serbia depend on those in Germany incomparably more than conditions in Germany depend on Serbia. Despite a solid long-term impact, there is not short run causality running from GerGDP to SrbGDP.

Keywords: VEC model, GDP, Germany, Serbia, economic growth.

\footnotetext{
${ }^{1}$ Economics Institute, Belgrade, Serbia. ivan.nikolic@ecinst.org.rs

2 Economics Institute, Belgrade, Serbia

${ }^{3}$ This paper is the result of research on the Project No. 179001 which is funded by the Ministry of Education, Science, and Technological Development of the Republic of Serbia
} 
Nikolić I., Zoroja M.: The Estimation of Long-run Relationship between Serbian...

\section{Ocena dugoročne međuzavisnosti ekonomskog rasta Srbije i Nemačke}

Apstrakt: Nemačka, od vajkada, trasira srpski ekonomski razvoj. Pošto je postala ekonomska i politička "super zvezda" Evrope ova njena uloga je danas još izraženija. Cilj ovog rada je da istraži upravo fundamentalnu ekonomsku vezu između Nemačke i Srpske privrede. Nakon uvodnog dela u kome smo se osvrnuli na investicionou aktivnost, spoljnotrgovinsku razmenu, broj zaposlenih, nove tehnologije itd. ocenili smo VEC model, sa kvartalnim BDP podacima u periodu 2004q1-2015q2. Dobijeni rezultati potvrđuju kointegracionu (dugoročnu) vezu između srpskog i nemačkog ekonomskog rasta. Statistički signifikantna negativna vrednost koeficijenta $\hat{e}_{t-1}$ ukazuje na to da srpski BDP reaguje na kvartalnu korekciju neravnoteže između Nemačke i Srbije. S druge strane, to se ne događa i sa nemačke strane jer je t-racio kod $\hat{e}_{t-1}$ statistički beznačajan. Time je potvrđena teza da ekonomski uslovi u Nemačkoj predodređuju dinamiku ekonomske aktivnosti u Srbiji, a ne obratno. Uprkos čvrstom dugoročnom uticaju, u kratkom roku nije statistički potvrđen uticaj nemačke konkjunture na srpski BDP.

Ključne reči: VEC model, BDP, Nemačka, Srbija, ekonomski rast.

\section{Introduction}

The aim of this paper is to explore the fundamental causal relationship between German and Serbian economy. Germany has always had an essential influence on Serbia's economic development. Today, Germany is Europe's economic and political superstar so this is even more pronounced. Particularly, due to the fact that in late 2015 Serbia opened first chapters in the EU membership negotiations.

European investors are the most important foreign investors in Serbia. In period from 2005 to the end of the third quarter of 2015 , more than $70 \%$ of net FDI in Serbia came from Europe. If we rank the countries of origin capital at net value of FDI for that period, Germany is in fifth place with 1,249 EUR millions $(7,8 \%$ of all investments), behind Australia, the Netherlands, Luxemburg and Norway (www.nbs.rs). In Serbia, there are more than 370 companies with a majority of German capital which employs nearly 25,000 workers (www.pks.rs).

German companies are active mainly in export-oriented sectors, contribute to reducing the overall trade deficit and a positive impact on the Serbian economy through technology transfer and the establishment of EU standards. 
Nikolić I., Zoroja M.: The Estimation of Long-run Relationship between Serbian...

Germany was Serbia's major foreign trade partner in imports (with 12,4\% share in total import), and second major partner in export after ltaly (with $12,6 \%$ share in total export) for the period January - November 2015. The export - import ratio equalled $75.3 \%$ and was higher if compared to the same period last year when it was $74.4 \%$. List of the first 5 imported products shows that Vehicles other than railway, tramway were the first imported product, followed by Machinery, nuclear reactors, boilers, etc., Plastics and articles thereof, Pharmaceutical products, and Electrical, electronic equipment. Serbia exported to Germany mainly Electrical, electronic equipment; then followed by Machinery, nuclear reactors, boilers, etc., Edible fruit, nuts, peel of citrus fruit, melons, and Parts \& access of motor vehicles (www.trademap.org).

Germany contributes to the Serbia's balance of payment deficit reduction also through high inflows of personal remittances i.e. personal transfers - current transfers between resident and non-resident households. According to the data of the Delegation of German Industry and Commerce in Serbia, the total number of Serbs living in Germany reached 320 thousand (http://serbien.ahk.de).

\section{Data and Methodologies}

In this study, we use a quarterly GDP growth rate data for $2004 q 1$ to $2015 q 2$ of Serbia (SerGDP) and Germany (GerGDP); variables are in natural logarithm. The data is retrieved from EUROSTAT database (http://ec.europa.eu/eurostat). The data on the GDP of Serbia and the Germany are used to estimate a Vector Error Correction Model (VECM).

A VAR model describes a system of equations in which each variable is a function of its own lag and the lag of the other variables in the system. A VECM is a special form of a VAR, which is used when two non-stationary variables are found to have a long-term relationship (co-integrated; Hamilton, 1994; Engle, R. F., and C. W. J. Granger. 1987). VECM is developed by Davidson et al (1978). The main idea of VECM is to include an error correction term which adjusts short-run fluctuation, thus enabling the model to capture both long-run and short-run properties.

VECM for Serbia's and Germany's GDP (SerGDP, GerGDP, respectively) is as follows:

$$
\begin{aligned}
& \triangle \operatorname{SerGDP} P_{t}=\alpha_{10}+\alpha_{11} \hat{\mathrm{e}}_{t-1}+v_{t}^{\operatorname{SerGDP} P} \\
& \triangle \operatorname{eerGDP}_{t}=\alpha_{20}+\alpha_{21} \hat{\mathrm{e}}_{t-1}+v_{t}^{G e r G D P}
\end{aligned}
$$


Nikolić I., Zoroja M.: The Estimation of Long-run Relationship between Serbian...

where $\hat{\mathrm{e}}_{t-1}$ are the lagged residuals from estimated equation: $\operatorname{SerGDP_{t}}$ $=\beta_{2} \operatorname{GerGDP_{t}}+e_{t}$. The intercept term is omitted because it has no economic meaning.

Figure 1. The first differences of the variable SerGDP and GerGDP

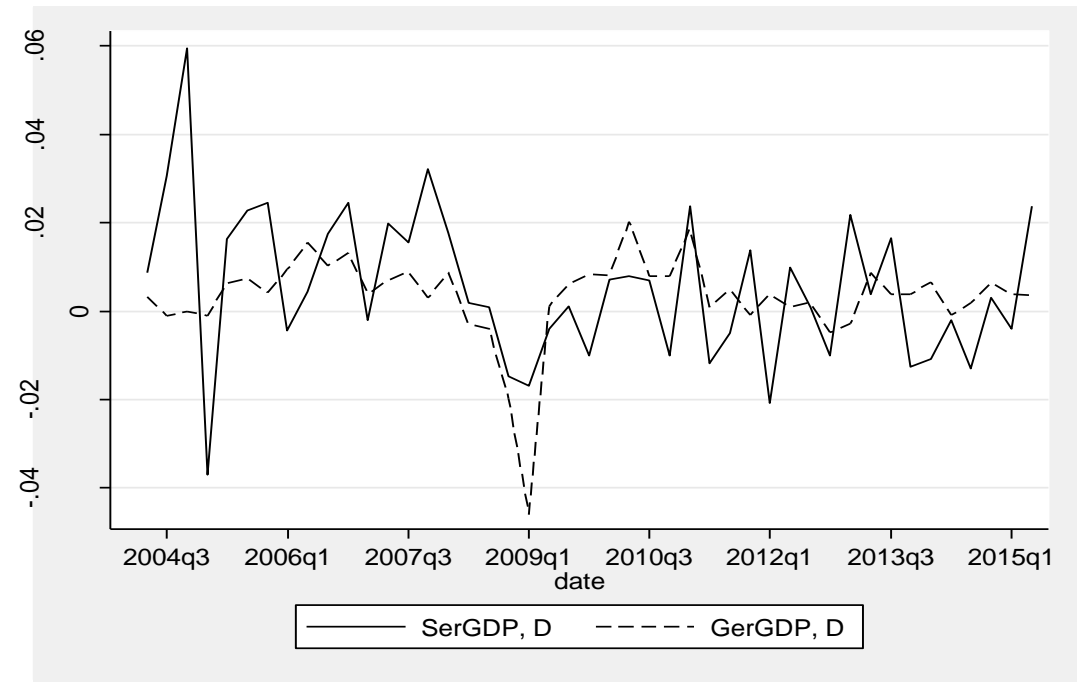

Source: EUROSTAT database; author's calculation

There are several different frameworks for estimation and inference in cointegrating systems. In this analysis, we will use two methods. First, a simple method as used by Lee C. Adkins and R. Carter Hill, (2011). The next one is Stata's default cointegration method based on Johansen's maximum likelihood framework, which allows us to perform post estimation tests and because it has been found to be particularly useful in several comparative studies, including: Zhuang Liu (2011), Lee C. Adkins and R. Carter Hill, (2011), Dungey, M., Vehbi, T. (2011), etc.

\section{Empirical Analysis and Results}

The first step in determining whether VAR or VEC model should be used is to conduct unit root tests to verify if time series are stationary. Formal unit root tests of the series confirm that they are indeed nonstationary i.e. we verify that the first differences of our both growth series are stationary. To be conservative, we include two lagged differences for Serbia to eliminate serial 
Nikolić I., Zoroja M.: The Estimation of Long-run Relationship between Serbian...

correlation in the error term of the Dickey-Fuller regression. Phillips-Perron tests lead to similar conclusions.

Table 1. Result of Augmented Dickey-Fuller test for unit root

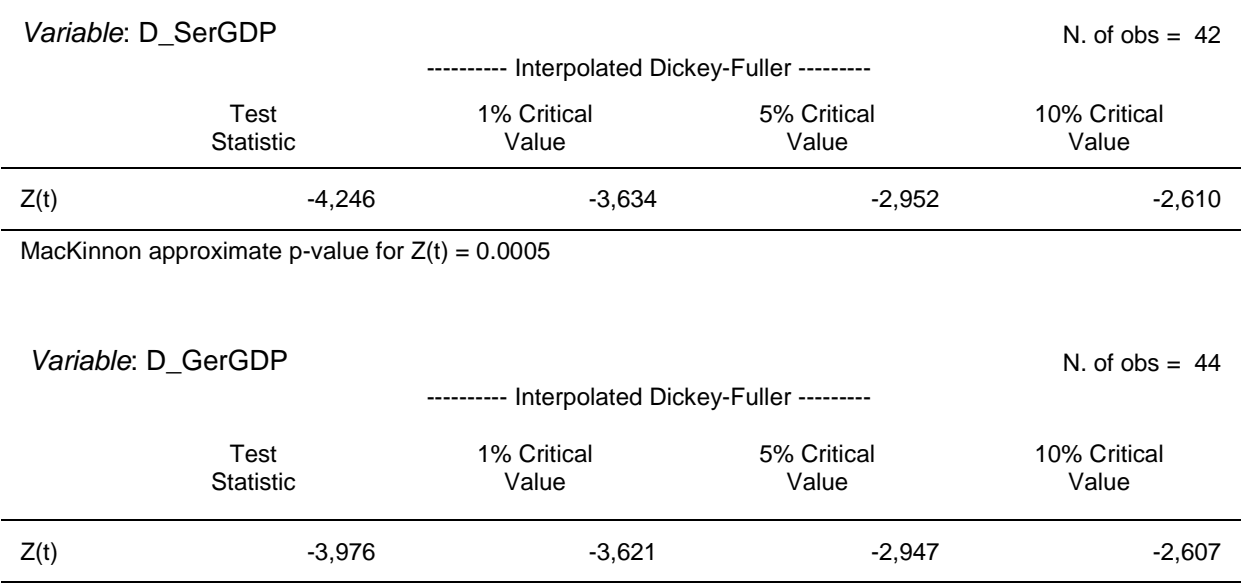

MacKinnon approximate $\mathrm{p}$-value for $\mathrm{Z}(\mathrm{t})=0.0015$

Source: authors' calculations

To check whether the variables SerGDP and GerGDP are cointegrated or spuriously related, we need to test the regression residuals for stationarity. To do this, we first estimate the following least squares equation.

Table 2. Estimated equation: $\operatorname{SerGDP} P_{t}=\beta_{2} \operatorname{GerGDP} P_{t}+e_{t}$

\begin{tabular}{|c|c|c|c|c|c|}
\hline \multirow[t]{2}{*}{ Source } & \multirow[t]{2}{*}{ SS } & \multirow[t]{2}{*}{ df } & \multirow[t]{2}{*}{ MS } & \multirow{2}{*}{$\begin{array}{r}\text { Number of obs }= \\
F(1,45)=\end{array}$} & 46 \\
\hline & & & & & - \\
\hline Model & 963,0147 & 1 & 963,0147 & Prob $>F=$ & 0 \\
\hline Residual & 0,080297 & 45 & 0,001784 & R-squared = & 0,9999 \\
\hline & & & & Adj R-squared = & 0,9999 \\
\hline Total & 936,095 & 46 & 20,93684 & Root MSE = & 0,0422 \\
\hline SerGDP & Coef. & Std.Err. & $\mathrm{t}$ & $P>|t|$ & Interval] \\
\hline GerGDP & 0,99237 & 0,00135 & 734,64 & 0,98964 & 0,99509 \\
\hline
\end{tabular}

Source: authors' calculations 
Nikolić I., Zoroja M.: The Estimation of Long-run Relationship between Serbian...

The intercept term is omitted because it has no economic meaning. Note that we have normalized on SerGDP because it makes more sense to think of a small economy responding to a large economy.

The residuals derived from the cointegrating relationship $\widehat{e_{t}}=\operatorname{SerGDP} P_{t}-$ 0,992 GerGDP $P_{t}$ are showen in next table after a formal unit root test is performed.

Table 3. The residuals derived from the cointegrating relationship

\begin{tabular}{|c|c|c|c|c|c|c|}
\hline \multirow[t]{2}{*}{ Source } & \multirow[t]{2}{*}{ SS } & \multirow[t]{2}{*}{ df } & \multirow[t]{2}{*}{ MS } & \multicolumn{2}{|c|}{ Number of obs $=$} & 45 \\
\hline & & & & \multicolumn{2}{|c|}{$F(1,44)=$} & 8,93 \\
\hline Model & 0,002246 & 1 & 0,002246 & \multicolumn{2}{|c|}{ Prob $>F=$} & 0,0046 \\
\hline Residual & 0,011067 & 44 & 0,000251 & \multicolumn{2}{|c|}{ R-squared $=$} & 0,1687 \\
\hline & & & & \multicolumn{2}{|c|}{ Adj R-squared = } & 0,1498 \\
\hline Total & 0,013313 & 45 & 0,000296 & \multicolumn{2}{|c|}{ Root MSE = } & 0,0159 \\
\hline D.ehat & Coef. & Std.Err. & $\mathrm{t}$ & $P>|t|$ & \multicolumn{2}{|c|}{ [95\% Conf. Interval] } \\
\hline $\begin{array}{l}\text { Ehat } \\
\text { L1. }\end{array}$ & $-0,16745$ & 0,05603 & $-2,99$ & 0,0050 & 0,28037 & $-0,05452$ \\
\hline
\end{tabular}

Source: authors' calculations

The $t$-ratio is equal to $-2,99$. Critical value of $5 \%$ for a cointegrating relationship with no intercept is $-2,76$ and therefore this falls within the rejection range of the test. The null hypothesis of no cointegration is rejected at $5 \%$ level of significance and we conclude that the two real GDP series are cointegrated. Thus, we can determine that economic activity in Serbia in the long-run is linked to economic activity in Germany. Moreover, if $\operatorname{GerGDP}_{t}$ were to increase by one percent $\operatorname{SerGDP}_{t}$ would increase by $0,99 \%$. But the Serbian economy may not respond fully by this amount in the shortrun. To ascertain how much it will respond within a quarter, we estimate the error correction model by least squares. The estimated VECM for \{SerGDP, GerGDP\} is:

$$
\begin{aligned}
& \operatorname{SerGD} P_{t}=0,005-0,1955 \hat{e}_{t-1} \\
& \text { (t) } \quad(-3,62) \\
& \widehat{G e r G D} P_{t}=0,003-0,0279 \hat{e}_{t-1} \\
& \text { (t) } \quad(-0,79)
\end{aligned}
$$

The significant negative coefficient on $\hat{e}_{t-1}$ indicates that Serbian GDP responds to a temporary disequilibrium between Serbia and Germany. The negative error correction coefficient in the first equation $(-0,195)$ indicates that 
Nikolić I., Zoroja M.: The Estimation of Long-run Relationship between Serbian...

$\triangle \operatorname{SerGDP}$ falls when there is a positive cointegrating error $\left(\hat{e}_{t-1}>0\right.$ or $\left.\operatorname{SerGDP} P_{t-1}>0,992 \operatorname{GerGDP} P_{t-1}\right)$. The error correction coefficient $(-0,195)$ is significant at the $5 \%$ level; it indicates that the quarterly adjustment of $\operatorname{SerGDP} P_{t}$ will be about $20 \%$ of the deviation of $\operatorname{SerGDP} P_{t-1}$ from its cointegrating value $0,995 \mathrm{GerGDP} P_{t-1}$. This is a moderate rate of adjustment.

Germany does not appear to respond to a disequilibrium between the two economies; the t-ratio on $\hat{e}_{t-1}$ is insignificant. These results support the idea that economic conditions in Serbia depend on those in Germany more than conditions in Germany depend on Serbia. In a simple model of two economy trade, Germany is a large economy and Serbia is a small open economy.

Unfortunately, the estimated model, in this manner, does not offer the possibility to obtain post estimation results. There are many diagnostics that will check for model misspecification, outliers, etc. To generate the post estimation diagnostics we had to repeat evaluation through the standard VECM procedure within STATA. By default, identification is obtained via the Johansen normalization.

First of all, to fit cointegrating VECMs, we must specify how many lags to include. Building on the work of Tsay (1984) and Paulsen (1984), Nielsen (2001) has shown that the methods can be used to determine the lag order for a VAR model with I(1) variables.

Table 4. Selection-order criteria

\begin{tabular}{|c|c|c|c|c|c|c|c|c|}
\hline \multicolumn{6}{|c|}{ Sample: $2005 q 1$ - $2015 q 2$} & \multirow{2}{*}{$\frac{\text { Vumber of obs }}{\text { AIC }}$} & \multicolumn{2}{|r|}{42} \\
\hline lag & LL & LR & df & $p$ & FPE & & HQIC & SBIC \\
\hline 0 & 159,379 & & & & 1,9E-06 & $-7,49423$ & $-7,46390$ & $-7,41148$ \\
\hline 1 & 257,485 & 196,21 & 4 & 0,000 & 2,2E-08 & $-11,9755$ & $-11,88450$ & $-11,7273^{*}$ \\
\hline 2 & 264,068 & $13,168^{*}$ & 4 & 0,010 & $1,9 e-08^{*}$ & $-12,0985^{*}$ & $-11,9468^{*}$ & $-1,2 \mathrm{E}+01$ \\
\hline 3 & 264,636 & 1,1352 & 4 & 0,889 & 2,3E-08 & $-11,9350$ & $-11,7227$ & $-1,1 \mathrm{E}+01$ \\
\hline 4 & 265,389 & 1,5058 & 4 & 0,826 & 2,7E-08 & $-11,7804$ & $-11,5074$ & $-1,1 \mathrm{E}+01$ \\
\hline
\end{tabular}

Endogenous: SerGDP GerGDP

Exogenous:_cons

Source: authors' calculations

We will use two lags for this bivariate model because the Hannan-Quinn information criterion (HQIC) method, sequential likelihood-ratio (LR) test and AIC criterion all chose two lags, as indicated by the "*” in the output.

The tests for cointegration are based on Johansen's method. These include the Johansen trace statistic method, the maximum eigenvalue statistic method, and a minimization of the information criterion. If the log likelihood of the unconstrained model that includes the cointegrating equations is significantly different from the log likelihood of the constrained model that 
Nikolić I., Zoroja M.: The Estimation of Long-run Relationship between Serbian...

does not include the cointegrating equations, we reject the null hypothesis of no cointegration. Table 5 displays the results of the Johansen tests:

Table 5. Johansen tests for cointegration

\begin{tabular}{|c|c|c|c|c|c|c|}
\hline \multicolumn{5}{|c|}{$\begin{array}{l}\text { Trend: constant } \\
\text { Sample: } 2004 q 4 \text { - } 2015 q 2\end{array}$} & \multicolumn{2}{|c|}{$\begin{aligned} \text { Number of obs } & =44 \\
\text { Lags } & =\quad 2\end{aligned}$} \\
\hline $\begin{array}{l}\text { maximum } \\
\text { rank }\end{array}$ & parms & LL & eigenvalue & $\begin{array}{c}\text { trace } \\
\text { statistic }\end{array}$ & $\begin{array}{l}5 \% \\
\text { critical } \\
\text { value }\end{array}$ & \\
\hline 0 & 6 & 263,76506 & - & 17,2970 & 15,41 & \\
\hline 1 & 9 & 271,49737 & 0,29635 & $1,8324^{*}$ & 3,76 & \\
\hline 2 & 10 & 272,41356 & 0,04079 & & & \\
\hline
\end{tabular}

Source: authors' calculations

Besides presenting information about the sample size and time span, the header indicates that test statistics are based on a model with two lags and a constant trend. In the output above, we strongly reject the null hypothesis of no cointegration and fail to reject the null hypothesis of at most one cointegrating equation. Thus we accept the null hypothesis that there is one cointegrating equation in the model.

Having determined that there is a cointegrating equation between the SerGDP and GerGDP we moved on to the estimation of the parameters of a bivariate cointegrating VECM for these two series.

The results indicate strong support for a cointegrating equation such that:

\section{SerGDP - 0,63643 GerGDP - 1,67117}

should be a stationary series. Identification of the parameters in the cointegrating equation is achieved by constraining some of them to be fixed, and fixed parameters do not have standard errors. The coefficient on SerGDP has been normalized to 1 , so its standard error is missing. The constant term in the cointegrating equation is not directly estimated in this trend specification but rather is backed out from other estimates.

Overall, the output indicates that the model fits well. Error correction term 0,2124 (i.e. speed of adjustment to long run equilibrium) has negative sign and also significant ( $P$ stat is less then $5 \%$ ), meaning that long run causality runs from German GDP to Serbian GDP. 
Nikolić I., Zoroja M.: The Estimation of Long-run Relationship between Serbian...

Table 6. Vector error-correction model

\begin{tabular}{|c|c|c|c|c|c|c|}
\hline \multirow{2}{*}{\multicolumn{4}{|c|}{ Sample: $2004 q 3$ - 2015q2 }} & \multirow{2}{*}{$\begin{array}{l}\text { o. of obs } \\
\text { IC }\end{array}$} & $=$ & 44 \\
\hline & & & & & $=$ & $-11,9317$ \\
\hline Log likeligood & $=$ & 271,4974 & & & $=$ & $-11,7964$ \\
\hline Det(Sigma_ml) & $=$ & $1,50 \mathrm{E}-08$ & & & $=$ & $-11,5668$ \\
\hline Equation & & Parms & RMSE & R-sq & chi2 & $\mathrm{P}>\mathrm{chi} 2$ \\
\hline D_SerGDP & & 4 & 0,01487 & 0,38550 & 25,08876 & 0,00000 \\
\hline D_GerGDP & & 4 & 0,00928 & 0,28800 & 16,17927 & 0,00280 \\
\hline
\end{tabular}

\begin{tabular}{|c|c|c|c|c|c|c|}
\hline & Coef. & Std. Err. & $z$ & $P>|z|$ & \multicolumn{2}{|c|}{ [95\% Conf. Interval] } \\
\hline $\begin{array}{r}\text {-ce1 } \\
\text { L1. }\end{array}$ & $-0,21243$ & 0,51933 & $-4,09$ & 0,000 & $-0,31422$ & $-0,11065$ \\
\hline $\begin{array}{r}\text { SerGDP } \\
\text { LD. }\end{array}$ & $-0,18163$ & 0,13956 & $-1,3$ & 0,193 & $-0,45516$ & 0,09190 \\
\hline $\begin{array}{r}\text { GerGDP } \\
\text { LD. }\end{array}$ & 0,22539 & 0,23752 & 0,95 & 0,343 & $-0,24013$ & 0,69091 \\
\hline _cons & $-0,00012$ & 0,00268 & $-0,05$ & 0,964 & $-0,00538$ & 0,00514 \\
\hline \multicolumn{7}{|l|}{ D_GerGDP } \\
\hline $\begin{array}{r}\text {-ce1 } \\
\text { L1. }\end{array}$ & $-0,18514$ & 0,32407 & $-0,57$ & 0,568 & $-0,08203$ & 0,04500 \\
\hline $\begin{array}{r}\text { SerGDP } \\
\text { LD. }\end{array}$ & $-0,01492$ & 0,08709 & $-0,17$ & 0,864 & $-0,18561$ & 0,15577 \\
\hline $\begin{array}{r}\text { GerGDP } \\
\text { LD. }\end{array}$ & 0,44441 & 0,14821 & 3,00 & 0,003 & 0,15392 & 0,73490 \\
\hline _cons & 0,00139 & 0,00167 & 0,83 & 0,407 & $-0,00189$ & 0,00467 \\
\hline
\end{tabular}

Cointegrating equations

\begin{tabular}{llrrr} 
Equation & Parms & & chi2 & \multicolumn{1}{c}{ P>chi2 } \\
\hline ce1 & 1 & 6,298 & 0,0121 \\
\hline
\end{tabular}

Identification: beta is exactly identified

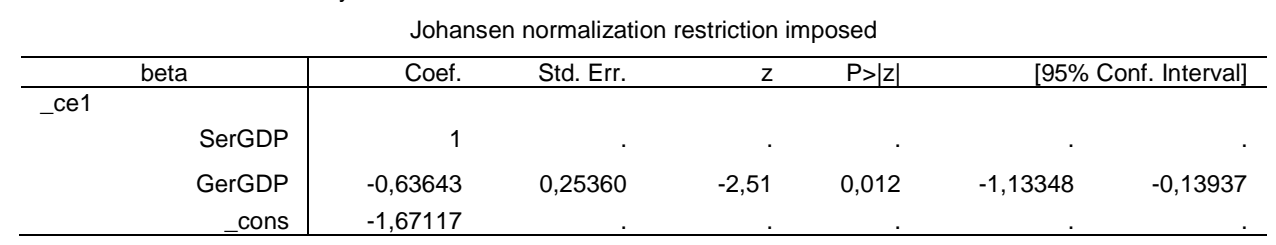

Source: authors' calculations 
Nikolić I., Zoroja M.: The Estimation of Long-run Relationship between Serbian...

The statistical procedure we use for testing short run causality among these two economies is:

\section{Table 7. Post estimation - Tests - Test linear hypotheses}

test ([D_SerGDP]: LD.GerGDP)

(1) [D_SerGDP]LD.GerGDP $=0$

$\operatorname{chi} 2(1)=0.90$

Prob $>$ chi2 $=0.3427$

Source: authors' calculations

Prob value is more than $5 \%$, so we can't reject $\mathrm{H} 0$, i.e. that means there is not short run causality running from GerGDP to SrbGDP.

Lagrange multiplier (LM) test for autocorrelation in the residuals of vector error-correction models follows:

Table 8. Lagrange-multiplier test

\begin{tabular}{rr|rrr}
\hline lag & chi2 & df & \multicolumn{1}{c}{ Prob > chi2 } \\
\hline & 1 & 1,2795 & 4 & 0,86485 \\
& 2 & 0,7218 & 4 & 0,94861 \\
\hline
\end{tabular}

Ho: no autocorrelation at lag order

Source: author's calculation

At the $5 \%$ level, we cannot reject the null hypothesis that there is no autocorrelation in the residuals for any of the orders tested. Thus this test finds no evidence of model misspecification.

For the first equation (D_SrbGDPs) we also computed tree statistics: a skewness, a kurtosis, and the Jarque-Bera, to test normally distributed disturbance.

Table 9. Tests for normally distributed disturbance

\begin{tabular}{|ccr|}
\hline \multicolumn{3}{|c}{ Jarque-Bera test } \\
\hline chi2 & df & Prob > chi2 \\
\hline 0,961 & 2 & 0,61844 \\
\hline
\end{tabular}

Source: author's calculation

\begin{tabular}{|ccc|}
\multicolumn{3}{|c}{ Skewness test: $-0,04698$} \\
\hline chi2 & df & Prob > chi2 \\
\hline 0,961 & 2 & 0,61844 \\
\hline
\end{tabular}

\begin{tabular}{|ccc|}
\multicolumn{3}{|c}{ Kurtosis test: 3,7179 } \\
\hline chi2 & df & Prob $>$ chi2 \\
\hline 0,961 & 2 & 0,61844 \\
\hline
\end{tabular}


Nikolić I., Zoroja M.: The Estimation of Long-run Relationship between Serbian...

The null hypothesis is that the disturbances in VECM are normally distributed i.e. failure to reject the null hypothesis indicates lack of model misspecification. None of these results shown above do not suggest nonnormality.

We should also evaluate the stability of the estimated VECM.

Table 10. Check for stability condition

\begin{tabular}{|c|r|}
\hline \multicolumn{1}{|c|}{ Eigenvalue } & \multicolumn{1}{c|}{ Modulus } \\
\hline 1 & 1 \\
0,8388788 & 0,838879 \\
0,4351567 & 0,435156 \\
$-0,2119053$ & 0,211905 \\
\hline
\end{tabular}

Source: author's calculation

For a $K$-variable model with $r$ cointegrating relationships, the companion matrix will have $K-r$ unit eigenvalues. For stability, the moduli of the remaining $r$ eigenvalues should be strictly less than unity. The table shows that one of the roots is 1 , and that there is a real root at about 0,84 . Although there is no distribution theory to measure how close this root is to one, per other discussions in the literature (Johansen, 1995), we conclude that the root of 0,84 supports our earlier analysis, in which we concluded that the predicted cointegrating equation is probably not stationary.

\section{Conclusions}

This paper provides statistical evidence (with VECM) that Serbian and German economy have significant long-run relationships, but only Serbian GDP responds to a temporary disequilibrium between Germany and Serbia. These results support the idea that economic conditions in Serbia depend on those in Germany incomparably more than conditions in Germany depend on Serbia. No doubt, this is consistent with the view that small economy is likely to react to economic conditions in large economy, but not vice versa. Nevertheless, it is important to point out that VECM's result do not find shortrun Granger causality from German to Serbian GDP.

Apart from the result, at least two limitations in this paper should be noted as well. First of all, the analysis only investigates the relationship statistically, doesn't provide insight into the underlying reason for their relationship. In the same manner, our research is only limited to the GDP data. It would be interesting to expand the study to some other variables. 
Nikolić I., Zoroja M.: The Estimation of Long-run Relationship between Serbian...

\section{References}

Davidson, J.E.H., Hendry, D.F., Srba, F., Yeo, J.S. (1978). Econometric modeling of the aggregate time--series relationship between consumers' expenditure and income in the United Kingdom. Economic Journal, 661-692

Dungey, M., Vehbi, T. (2011). Modelling East Asia economics in a small open economy VECM: The inferences of international and domestic shocks, Manuscript Australian National University, University of Cambridge and University of Tasmania

Engle, R.F., \& Granger, C.W.J.(1987). Co-integration and error correction: Representation, estimation, and testing, Econometrica, 55: 251-276.

Hamilton, J.D. (1994). Time Series Analysis, Princeton University Press, Princeton, NJ

Lee C., Adkins and R. Carter Hill (2011). Using Stata for Principles of Econometrics, Fourth Edition, Stata Press, 407-412.

Liu Zhuang (2011). Time Series Analysis of China and Africa's GDP: A Case of Sudan, Proceedings of The 2011 International Symposium —Technical Innovation of Industrial Transformation and Structural Adjustment

Nielsen, B. (2001). Order determination in general vector autoregressions, Working paper, Department of Economics, University of Oxford and Nuffield College

Paulsen, J. (1984), Order determination of multivariate autoregressive time series with unit roots, Journal of Time Series Analysis 5: 115-127.

Tsay, R. S. (1984). Order selection in nonstationary autoregressive models, Annals of Statistics 12: 1425-1433.

http://www.nbs.rs/internet/english/80/platni bilans.html

http://www.pks.rs/Vesti.aspx?IDVestiDogadjaji=16268\&idjezik=1

http://serbien.ahk.de/rs/

www.trademap.org

http://ec.europa.eu/eurostat 